\title{
The African Origins of Greek Philosophy: Ancient Egypt in Retrospect
}

\author{
Nicholas Chukwudike Anakwue \\ https://orcid.org/0000-0002-3053-7541 \\ Lagos Business School, Ajah \\ nikibertx@gmail.com
}

\begin{abstract}
The demand of philosophising in Africa has faced a history of criticism that has been particularly Eurocentric and strongly biased. However, that trend is changing with the emergence of core philosophical thinking in Africa. This paper is an attempt to articulate a singular issue in this evolution - the originality of African philosophy, through Ancient Egypt and its influence on Greek philosophy. The paper sets about this task by first exposing the historical debate on the early beginnings of the philosophical enterprise, with a view to establishing the possibility of philosophical influences in Africa. It then goes ahead to posit the three hypotheses that link Greek philosophy to have developed from the cultural materiality of Ancient Egypt, and the Eurocentric travesty of history in recognising influences of philosophy as from Europe alone, apart from Egypt.
\end{abstract}

Keywords: African philosophy; Greece; Egypt; colonialism; Eurocentrism; Hegel; negrity; culture; hermeneutics

\section{UNISA $\cong$}




\section{Introduction}

The perplexing saga of colonialism in Africa and the scandal of the follow-up Western denigration of Africa's image have predominantly engendered the interest of recent scholarship in Africa, to generally seek to define and reconstruct the African identity (Osuagwu 1999, 68). This determined effort at restoration is geared primarily towards achieving freedom and development in Africa without any compromise to its already misconstrued identity (Oladipo 1995, 26); beset, as it were, by the disconcerting barrage of half-truths about her history and a consequent displacement from her locus of culture (Dike 1985, xi). This African historical trajectory has witnessed constantly the portrayal of Africa in negative and prejudiced light, devoid of rationality, philosophy, society, civilisation and consequently, a history. Hegel, in this regard, erroneously expresses Africa as being of "no historical part of the world," and hence, possessive of "no movement or development to exhibit" (Hegel 1956, 92). While Hegel is to be regarded as utterly mistaken in his assertion, it is apposite to note that, as at an earlier time, the current geographical distinctions of continents were not as politically defined as we have now.

It is in this regard that the prerogative of rationality and science, denied the African continent, was ascribed, prima facie, to the Western mindset. Consequently, given the point of a paradigm of rationality serving as one of the cardinal concepts undergirding the subject matter of philosophy, the formal enterprise of philosophy is said to basically originate in the West, in the wonder of the Greek civilisation (Olu-Owolabi 2011, 14). Still, it would be unfair to wrongly assume that Greek philosophy possesses no originality of its own, as every culture is seed for the development of philosophical thought. However, the previous denial of the reflective spirit to Africa cannot be consistent with the hackneyed notion that Greek philosophy, which is the epicentre from which all the waves of the philosophic current emanate, has its foundations in the characterised "Dark Continent" of Africa (Jarosz 1992, 105-115) — to be exact, most especially in Ancient Egypt.

This new outlook has provided a subtle and necessary shift from the question of identity to the pertinent issue of African originality. As against the jaundiced view of Frederick Copleston, who argued for the inviolability of the dogma of the "compulsive originality" of Greek philosophy (Copleston 1993, 11), the counter-argument is hinged on the allegation of "the nature of the intellectual influence on specific Greek philosophers of merit by the 
Ancient African Worldview" (Olela 1984, 77). This invariably seeks to assume an African philosophy that predates the Greek civilisation. This stance, then, provides avenue for the consequent attempt at reconstruction, construction and hence, re-establishment of the historicity, antiquity, Africanity and negrity of Ancient Egyptian philosophy (Osuagwu 1999, 91).

As such, this paper seeks to present Egypt, and on a broader scale Africa, as part of the undercurrents of a culture of philosophising that gave rise to the growth and expansion of philosophy in Europe and in the world. This is because philosophies grow and influence each other upon contact, as their development cannot be achieved in vacuo.

\section{Philosophy and Culture}

Firstly, an analysis of the term "philosophy," in its etymological sense, will supply us with the notorious cliché, "love of wisdom," which when further elaborated, expresses philosophy to represent "the effort of the human reason to provide the last answer to the inquiring mind in its apparently elusive effort to find an explanatory anchor that imparts meaning to life, explaining its origin, giving direction to its activities and providing goals for its quest" [own italics] (Oguejiofor and Onah 2001, xvii). From this above definition of philosophy, one can

highlight two paradigmatic ingredients intrinsic to identifying the philosophic spirit, namely, the ideas of "rationality" and "value." The former, here, represents the instrument that enables the realisation of the goals of philosophy, while the latter represents the goals that philosophy attempts to grasp (Olu-Owolabi 2011, 18). These two standards can aid in retracing the history and possibly even the beginnings of philosophy, as every history needs to evidently have a beginning. Keeping these aforementioned standards in mind, and seeking, hence, to reconstruct the history of philosophy to its absolute beginnings, one would require identifying the very origins of man. This is consequent upon the fact that since philosophy is a function of rationality - which in turn is an essential characteristic of the human person-it follows that the history of philosophy would basically be coterminous with the history of humanity. It is against this backdrop that the privilege of an African rationality, and consequently of a possible African beginning of philosophy, was expelled from the entire historical picture, as Africa herself was ultimately denied any modicum of humanity. 
However, we must avoid the trappings of any racial bias in understanding the role of culture in the emergence and development of philosophy. African scholars have attempted to characterise the African temper, describing it as unique to the African mind and the possession of a personality starkly varied from, but not in any way inferior to, the European personality (Oladipo 1995, 27). For how was it possible that a people-devoid of rationality or the possibility of development-were able to create the magnificence of the ancient civilisations that marked Africa's historical development, in Ancient Egypt, Ethiopia, Ghana and various parts of Africa? And how could one refuse Africa the basic essence of humanity in the face of her very many exploits and evidences of a complex rationality? Drawing from this support, and the aforementioned synonymy of a history of philosophy with a history of man, it is assumed that man has, ab initio, persistently sought to interpret his world in vivid and significant symbols of culture (Osuagwu 2005, 57). Culture, then, expresses the totality of the way of life of a people and the acquisition over time of knowledge of one's proximate world, either subjectively or objectively, intrinsically or extrinsically (Otite and Ogionwo 1979, 44). Wiredu notes carefully, that culture simply transcends the narrow context of art, song and dance, to the varied distinctive ways of investigating nature and utilising its possibilities in praxis, in viewing oneself in nature and interpreting one's place in nature (Wiredu quoted in Oladipo 1995, 30). Also, an understanding of reality enabled development of values and virtues, which in turn overlapped in a "mutually reinforced symbiosis," shaping progressively the entire context of one's personal and social life. It is consequently, within this unique context, that children were raised and cultivated; hence "the term 'culture' as the way to cultivate the soul" (McLean 2005, 300).

As a follow-up to the aforementioned there should be the support of a dialectical nexus between the aspects of philosophy and culture. Philosophers argue that culture, like nature, was basically at the core of philosophy, being the "background, basis, preoccupation and inspiration of the philosopher's mission" (Osuagwu 2005, 55). In this regard, Okere supports the concept of a philosophy of non-philosophy (Okere quoted in Osuagwu 2005, 49). He regards culture by the distinctive term of "philosopheme," which for him is the basic raw material of philosophy, for just as philosophy was to rely on culture for its material, so also philosophy could be attested to constitute "one of the cultural activities of humanity," being not the least, nor the best, but merely unique and indispensable (Osuagwu 2005, 55). 
Nonetheless, not all philosophic activity is necessarily cultural, as some are justifiable under religion, such as ethics.

Africa is attested to possess the heritage of a very rich legacy of culture, as also recent findings demonstrate strongly its reflection in works of antiquity, of an abundance of artistic and religious temperaments in Ancient Africa (Stride 1971, 162). The African Weltanshauung $^{1}$ is thus a characteristically rich embodiment of such cultural expression, in parables, folktales, myths and proverbs. This wealth of African philosophical material is, however, limited by the dearth of a written tradition. It is also often argued that there is no part of the world where men do not engage in reflection, in search for answers or explanations, which itself is descriptive of philosophy. Philosophy, in this sense, is then understood as reflection on man's experience, either of himself (subjectivity) or of his world (objectivity) (Omoregbe 1998, 3-5). As a particular author notes further:

Historically, Africa may have lagged behind Europe in terms of technology. However, long before the coming of Europeans to the continent, Africans possessed social and political philosophies as valid as those of their European counterparts. These systems revolved around a universal recognition of human worth which formed the spiritual foundation of African societies. (Kochalumchuvattil 2010, 109)

The above, therefore, suggests the exigency of a hermeneutics to adjudicate the relationship between culture and philosophy. Hermeneutics, here, implies an understanding with the underlying theme of an interdependence regarding knowledge of the parts and knowledge of the whole. Hence, every interpretation is essentially expressed in "fore-having, fore-sight and fore-conception" (Enweh 2005, 179). This permits the ideal of a critical and reconstructive evaluation of the African worldview with the aim of arriving at reflection, which is philosophy (Osuagwu 2005, 55-57). Hermeneutics, therefore, allows the context for the possibility of a transition from African culture to African philosophy. Based on this inalienable fact, historical evidence establishes the very wonder of a nascent philosophical growth in the Ancient Egyptian culture in Africa.

1 A German phrase, meaning "worldview." 


\section{The African Legacy of Egyptian Philosophy}

The question as to whether that which existed in Egypt was to be termed philosophy, remains debatable, given the plethora of divergent views concerning it. Copleston (1993) argues that one's preoccupation should not be with the influence of Greek philosophy from Egypt, but with the question of whether "the people in question [Egypt] really possessed a philosophy," for he opines that it had never been shown that what they had communicated to the world was indeed a philosophy. He then concludes that the Greeks stand out as the uncontested original thinkers and scientists of Europe (Copleston 1993, 15). It is important to note that Greek philosophy was likewise influenced by other cultures, apart from Egypt, within Europe.

Supporting this aforesaid viewpoint as against a romantic glorification and attachment to the historic past, Odera Oruka (in Oruka and Masolo 1983) points out that philosophy should be built around the individual rather than the community, and not as an open denial of "Plato's maxim that the multitude cannot be philosophic" (Owolabi 1999, 61). Philosophy is, therefore, described as egologic (cogito) and not ethnologic, for collective philosophy implies total consensus, total adherence, total unity and uniformity. Rather, philosophy-being based on the need for critical analysis - is "often a mise-en-cause, and a radical questioning of the collective image ... to give meaning to one's world" (Osuagwu 2005, 58-59). By way of a counter-critique, Omoregbe $(1998,5-6)$ argues that the African Weltanshauung did not simply arise in a vacuum but rather gives testimony to the avid reflections of some gifted individual thinkers, whom he calls "African philosophers of the past." Consequently, Omoregbe submits that it is too ambitious to assume these thoughts to originate from a collective consciousness or a community consciousness, for thinking is, ipso facto, done only by individuals (Omoregbe 1998, 5-6). Against a further accusation that the systems in ancient Egypt lacked supportive arguments, and so could not be constituted as philosophy, Omoregbe (1998, 4-5) counters with a clarification of the concept of philosophy to imply the process of reflection, or the "systematic reflective thinking on life" (Yu-lan 1976, 16) and not the Western-type argumentation. This, for Omoregbe, is abundantly evident in the philosophical systems of Egypt.

In the face of this barrage of responses and counter-responses, the attempt to sound the knell on the entire argument leads ultimately to positing the argument that "Egypt ... does not belong to the African spirit" (Hegel 1956, 99). This argument precludes any possibility that 
such great culture and civilisation could not have come from Africa. The error of this assertion is not only geographically faulty, but also blindly chauvinistic. Keita (1984) points out, recalling this unfair distortion of history, that “... the history of Ancient Egypt was severed from the history of the African world and was considered henceforth as part of the Oriental World" (Keita 1984, 57). However, recent findings have dismissed this longstanding thesis on Egypt, as the Cairo Symposium revealed the historical fact of the cultural forms of Ancient Egypt belonging to Africa. This served as a turning point in African historiography and philosophy, as it authenticated the African heritage of an Egyptian philosophy (Obenga 2004, 33). In spite of this, one must realise that the cultural ties that Ancient Greece shared with Egypt should not be trivialised in a bid to represent Egypt as distinctly African. This is so as to avoid playing the racial card in a history that goes beyond political and geographical biases.

By way of analysis, therefore, philosophy in Egypt arose around the Nile Valley, in Kemet or ancient Egypt, and in Kush (Napata-Meroe). It thrived considerably in Egypt from about $3400 \mathrm{BC}$ to $343 \mathrm{BC}$ and in Kush, also known as Nubia or Ethiopia by the Greeks, from about $1000 \mathrm{BC}$ to $625 \mathrm{BC}$. Egyptian philosophy was replete with aphorisms, allusions, metaphors, negative or positive methods, and dialectics that demonstrated the speculative reflective ability of the people (Obenga 2004, 31). This may have originated in Mesopotamia.

Firstly, the Egyptians conceived of philosophy as consonant with its basic notion of "love of wisdom." Philosophy was, then, not solely concerned with speculation and reflection on life and nature, but was also preoccupied with love, intense desire and strong enthusiasm in the investigation of causes underlying reality; with the ultimate aim of providing a system of values to serve as a guide to societal living. It was understood as the synthesis of all learning and the pursuit of wisdom and moral and spiritual perfection. It was a pedagogy encapsulating the wise teachings (sebayit) of the old sages. The verb rekh, meaning "to know," which was denoted with the image of "mouth," "placenta" and "papyrus rolled up, tied and sealed," served as the etymological basis for "a wise man" - that is, a learned man, or a philosopher. The word rekhet was said to imply "knowledge" or "science" in the sense of "philosophy." The word seba, meaning "to teach" also suggests a methodological process of imparting knowledge, such as can be seen in a school. The wise man can be said to teach $(s e b a)$ in order to open the door (seba) to the mind of the pupil (seba) so as to bring light, as 
from a star $(\operatorname{seba})$. By consequence, the wise man is said to attempt to grasp with clarity and certainty, knowledge, which should ultimately lead him to truth (Maat) (Obenga 2004, 3540).

This idea of Maat stands out as one of the key concepts of Egyptian philosophy, as it expresses the embodiment of perfect virtue. It implies what was "real" or "reality" as that which is genuine and authentic against the bogus. Maat consists in all things that possess actuality, existence or essence; transcending all realms of reality to the divine or sacred, the cosmic, the physical, the political and the familial. A just society was a manifestation of Maat, for it expressed other crucial meanings of "truth," "justice," "righteousness," and "rightness." It was, therefore, the highest physical or moral law known to Ancient Egyptians. People did not, therefore, live in the characterised Hobbesian state of nature that was poor, solitary, nasty, brutish and short. They lived, rather, in the light of the principles of right conduct. The Pharaoh was, therefore, not simply politically or morally distinguished; he was truly a real (Maa) king, a divine leader and a spiritual king, using divine principles of the Maat to govern his empire (Obenga 2004, 46-48).

Coupled with this important conception of reality, the Egyptians possessed a revolutionary concept of "existence." The verb "to exist" was designated by the term "wnn" (unen), written with the image of a long-eared desert hare. This implied a characteristic dynamism that involved a true "being capable" of movement. Hence, non-being for the Egyptian was static. This excludes from the category of being, illusion, delusion and ordinary sense impression. Therefore, this concept of "being" is crucial to the concept of "universe," which had the material sun $(R a)$, known as the "sun-god" at the centre, ordering all things. The dichotomy existing between the concepts of "chaos" and "cosmos" as extremely antithetical concepts is dispelled; for the Egyptian mind has no concept of chaos; in the beginning, $R a$ emerges from primordial space and time, by his own energy, to initiate the creation of the world (Obenga 2004, 33-42).

Egypt also developed the tool of logic as a principle of reasoning, to deal rationally with the problems they encountered, utilising a systematic, logical, inferential methodology. They made use of logic as a tool of precision in constructing and developing their mathematics (Obenga 2004, 41). 
Summarily, a careful consideration of these foregoing elements of the Ancient Egyptian mystery system would reveal the presence of a well-developed philosophy, which sought to express the basic requirements of reflection, critical analysis and logicality. It was the realisation of this great contribution of Egypt to the world that, accordingly, led individual Greek philosophers to arrive on the shores of the African continent, with the purpose of receiving formal education on this complex Egyptian system.

\section{Ancient Egypt and Greek Philosophy}

The city of Ionia in Greece is alleged to have begun the slow but steady transition from "myth" to philosophy. They were regarded as the progenitors of the philosophical discipline and the cradle of Western thought. Despite the undue preoccupation with the utility of observation over pure reason, they are nonetheless acclaimed to have been the original initiators of a gradual shift from cosmogony to logos. In an attempt to overemphasise the marvel of the Greek genius, there is blank refusal in acknowledging the vital role Africa played in setting into motion this celebrated dynamic shift of thought that gave the consequence of philosophy. By way of lending support to this untruthful stance, Copleston (1993, 15-16) argues indignantly that - despite the interactions, he confesses, that existed between the Greek world and Egypt in Africa, and the consequent supply of a preliminary material that served to furnish the great early Ionian thinkers, namely, Thales, Anaximander and Anaximenes, with the stuff for philosophical inquiry - this was not to be reckoned as philosophical in itself, but was rather useful to the Ionians, to whom its originality is credited.

Drawing upon the foregoing hint of a vibrant interaction between Greece and Egypt around the time of Thales, Russell $(1996,25-26)$ develops this idea by recounting that a great civilisation had existed in Egypt, particularly due to the benefit of the Nile, the Tigris and the Euphrates, which made agriculture very easy and productive. There existed a divine king with despotic powers, as well as a polytheistic religion and a military and priestly aristocracy. Russell (1996) traces the inheritance of an Egyptian civilisation by the Greeks from the commercial interactions of Crete, which possessed the Minoan culture, with Egypt, to the hypothesis of the dispersal of the Cretan civilisation in Greece either as progenitors of the Greek race, or as colonisers of the then resident Greeks. The Greeks then came to Greece, in the three different waves; firstly, the Ionians, the Achaeans and finally, the Dorians. The 
Ionians, whom we are concerned with, were alleged to have adopted the aforesaid Cretan civilisation completely (Russell 1996, 27-32). This served as the definite backdrop to the arrival of the great Ionian thinkers in Thales, Anaximander and Anaximenes.

Against this background influence existing between Ionia in Greece and Egypt, some ideas already present in the cosmologies of Greece possessed a striking semblance to the prior Egyptian system. One notable idea was the expediency of balance between right and wrong in the life of an individual, which led to the prevention of chaos and anarchy. This did away with the idea of a universe governed by mere caprice, a lawless spontaneity or a lawless and "egoistic" domination of one element over the other, and proposed the concept of a lawgoverned universe (Copleston 1993, 21). This is consistent with the already discussed Egyptian concept of Maat. Also, the Greek cosmologists perceived existence as an entailing motion. This motion they observed in change and transition from life to death and from death to life (Copleston 1993, 19-20). This idea was also consistent with the Egyptian notion of change as the primary characteristic of an existent being.

It was from this cosmological backdrop that Thales, who is debatably regarded to be the first philosopher, emerged. However, evidence has it that Thales travelled to Egypt to learn the science of geometry. It could also be deduced that Thales had the opportunity of acquainting himself with other things as well, such as the current philosophical thought in Egypt, the science of logic, and so forth (Russell 1996, 45). Plato himself records to that effect that Thales was educated in Egypt under the priests (Plato, The Republic X, 600 A). Other Greek philosophers of note are also alleged to have developed to a large extent their philosophic currents from contact with Egypt. Philosophers such as Xenophanes, Parmenides, Zeno, Melissus, Heraclitus, Empedocles, Anaxagoras and Democritus were all alleged to have had contact with the Ancient Egyptian worldview. It is also worthy of note that even the ancient philosophers of Greece did not give in to the deceit of appropriating the authorship of philosophy, for they were well aware of the primacy of the then existent Egyptian thought. Apart from these noteworthy philosophers, Plato is also regarded to have visited Euclid at Megara, together with other pupils of Socrates, and constantly shuttled to and from Egypt for the purpose of instruction by the Egyptian priests (George 1954, 35). 
Given the argument that the Greek philosophers were persecuted for the propagation of their various philosophies, it can be deduced that the Greek people were averse to this intellectual upsurge particularly because of its foreign nature, rather than because of its radicalism (George 1954, 25). Many of the Greeks felt that this alien intellectual current was going to displace their political hold on the Greek society and way of life. As such, philosophers like Socrates had to pay with their life's blood.

Summarily, scholars have posited three varied hypotheses to account for the historical origins of Greek philosophy. Firstly, the Aryan model supports the influence of Ancient Egypt and other ancient traditions on Greek philosophy. This allows for a Hellenocentric and Europacentric standpoint, arguing the originality of a "Greek mentality" that existed and the helpful influence of extrinsic ideologies, not sufficient to be termed "philosophy," that enabled it to arrive at pure philosophising. On this level of theorising it is held that possibly what existed in Egypt was still on the rung of "philosopheme" and had not yet become core philosophising, still couched in cultural terms and limitations. This does not deny that Greek philosophy had further influences from cultures other than Egyptian.

Secondly, the Afrocentric model is put forward to deny the Greek originality and rather exposes the historical theft of the Egyptian philosophical legacy. Greek philosophers are hypothesised to have come to Egypt to garner wisdom and then taken these to the shores of their country, Greece, where the historical lie of philosophy beginning in Ionia is brandished.

Finally, the communicational (diffusionist) hypothesis expresses the emergence of a new cultural form based on the interaction between Greek and Egyptian cultures that allowed for the development of philosophy. This puts both cultures at par with themselves and posits the inevitable existence of a reciprocal flow of information, creative interaction and exchange (Dungen 2012). On this last basis, a new culture of philosophy is achieved on the interaction between both cultures and their historical and cultural antecedents.

\section{Conclusion}

Given the entire trajectory of the whole argument put forward to examine the notion of Greek philosophy having its foundations in Africa, it appears evident that such allegation is consistent with the body of evidence to support the said dependence of what is known as 
Greek philosophy, with the entire corpus of Ancient Egyptian tradition. The question that becomes ever essential, however, is the extent of such relationship, which is itself consequent on the nature of the tradition Egypt was in possession of. For if one were to arrive at the fact of such tradition constituting a philosophy, as this paper argues, then it would follow as a matter of consequence that Egypt is the unacknowledged progenitor of the philosophical enterprise. Hegel (quoted in Law 1976) stresses the obligation of historians getting their "facts" right, despite his disloyalty with regard to obeying this injunction (Law 1976, 103132). In keeping with this precept it is without doubt that, on the issue of African originality, Africa is to be credited with the wonder of an Ancient Egyptian philosophy. This, in turn, will chiefly aid in reconstructing an African philosophy to allow for development in Africa amidst all the present socio-political challenges; hence reclaiming the pride of Africa. Nonetheless, irrespective of this preceding view, one should not be led to indignantly and blindly deny the equally praiseworthy mark of the Greek genius, for despite the influence of an "Egyptian philosophy" on the spontaneous birth of philosophy in Europe in the Greek civilisation, the subsequent growth of the enterprise was built largely upon the particular culture characteristic of Europe.

In conclusion, therefore, it is manifest that Greek philosophy can be reliably traced to African influences. This understanding of the origins of Greek philosophy can orient one to realising the importance of Africa on the development of philosophical thinking and the consequent place of African philosophy on a global scale. Africa has never been alien to philosophical thinking and the rigors of the philosophical spirit, like different thinkers have been so harsh in categorising Africa. Greek philosophy, however, does not have to justify its use by Western chauvinists to sport the notion of an Africa without a philosophy. Africa has seen the growth of original philosophical ideas and is in no way alien to the philosophical spirit. A banal proof of this lies in the theory that democracy, in its primitive form, seemed to emerge around pre-Babylonian Mesopotamia, where power was in the hands of free male citizens, largely similar to the new-age "government of the people, by the people and for the people." Mesopotamia itself was a blend of different cultures and peoples. Democracy and property rights that took their conceptual clarity in Greek philosophising had already been in practice, in various forms, in Mesopotamia and India. As such, the growth and development of philosophic attitudes do not just happen in a vacuum; they are spurred on by influences from other cultural niches. In this stead, Africa has something to offer. It has the wealth of a vast 
cultural and philosophical richness that can furnish us with tools to aid and hasten philosophical development and the emancipation of the African continent from the shackles of post-colonial trauma and depression.

\section{References}

Copleston, F. 1993. A History of Philosophy, vol. I. New York: Doubleday Publishers.

Dike, A. 1985. The Resilience of Igbo Culture: A Case Study of Awka Town. Enugu: Fourth Dimension Publishers.

Dungen, W. “Ancient Egypt: Impact of Ancient Egypt on Greek Philosophy.” Sofiatopia $\mathrm{http} / / / \mathrm{www} . \mathrm{maat}$.sofiatopia.org/hermes1.htm (accessed 4 December2012).

Enweh, J. 2005. "Philosophy vs. Hume: Between Ruinance and Endowing." In African Philosophy and the Hermeneutics of Culture, edited by J. O. Oguejiofor and G. I. Onah. Enugu: Transaction Publishers.

George, M. J. 1954. Stolen Legacy: Greek Philosophy is Egyptian Philosophy. New York: Philosophical Library.

Hegel, G. W. F. 1956 (2004). The Philosophy of History, translated by J. Sibree and C. Hegel. New York: Dover Publications.

Jarosz, L. 1992. "Constructing the Dark Continent: Metaphor as Geographic Representation of Africa." Geografiska Annaler 74B (2): 105-115. https://doi.org/10.2307/490566; https://doi.org/10.1080/04353684.1992.11879634.

Keita, J. 1984. "The African Philosophical Tradition." In African Philosophy: An Introduction, edited by R. A. Wright. Lanham: University Press of America, as quoted in Osuagwu, M. I. 1999. African Historical Reconstruction, vol. I. Owerri: Assumpta Press.

Kochalumchuvattil, T. 2010. "The Crisis of Identity in Africa: A Call for Subjectivity." Kritke 4 (1): 108-122. https://doi.org/10.25138/4.1.a.8.

Law, R. C. C. 1976. "The Northern Factor in Yoruba History." In Proceedings of the Conference on Yoruba Civilization: Ile-Ife (2 vols.) vol. I, 1977, 103-132, edited by I. A. Akinjogbin and G. Ekemode.

McLean, G. F. 2005. "Globalization as Dialogue of Culture from Conflict to Convergence." In African Philosophy and the Hermeneutics of Culture, edited by J. O. Oguejiofor and G. I. Onah. Enugu: Transaction Publishers.

Obenga, T. 2004. "Egypt: Ancient History of African Philosophy." In A Companion to African Philosophy, edited by K. Wiredu. Massachussets: Blackwell Publishers.

Oguejiofor, J. O., and G. I. Onah 2005. African Philosophy and the Hermeneutics of Culture. Enugu: Transaction Publishers.

Oladipo, O. 1992. The Idea of African Philosophy. Ibadan: Hope Publications.

Oladipo, O. 1995. "Reason, Identity and the African Quest: The Problems of Self-Definition in 
African Philosophy." Africa Today 42 (3): 26-38.

Olela, H. 1984. “The African Foundations of Greek Philosophy.” In African Philosophy: An introduction, edited by R. A. Wright. Lanham: University Press of America, as quoted in Osuagwu, M. I. 1999. African Historical Reconstruction, vol. I. Owerri: Assumpta Press.

Olu-Owolabi, K. A. 2011. "My People Perish for Lack of Philosophy." Inaugural Lecture at the University of Ibadan, Ibadan, Oyo State.

Omoregbe, J. I. 1998. “African Philosophy: Yesterday and Today.” In African Philosophy: An Anthology, edited by C. E. Eze. Massachusetts: Blackwell Publishers.

Oruka, O. H., and D. A. Masolo (eds). 1983. Philosophy and Cultures. Nairobi: Bookwise Publishers.

Osuagwu, M. I. 1999. African Historical Reconstruction, vol. I. Owerri: Assumpta Press.

Osuagwu, M. I. 2005. "Philosophy of Non-Philosophy: Okere's Trilogy on African philosophy.” In African Philosophy and the Hermeneutics of Culture, edited by J. O. Oguejiofor and G. I. Onah. Enugu: Transaction Publishers.

Otite, O., and W. Ogionwo. 1979. An Introduction to Sociological Studies. Ibadan: Heinemann.

Owolabi, K. A. 1999. "Orientations in African Philosophy: A Critical Survey.” Indian Philosophical Quarterly xxvi (1): 59-70.

Plato. 2000. The Republic, translated by Tom Griffith. Cambridge: Cambridge University Press.

Russell, B. 1996. History of Western Philosophy. London: Routledge.

Stride, G. T. 1971. Peoples and Empires of West Africa: West Africa in History 1000-1800. Ijebu-Ife: Nelson Publications.

Yu-lan, F. 1976. A Short History of Chinese Philosophy. New York: The Free Press. 